\title{
Serum polychlorinated biphenyl and organochlorine insecticide concentrations in a Faroese birth cohort
}

\section{Citation}

Barr, Dana B., Pál Weihe, Mark D. Davis, Larry L. Needham, and Philippe Grandjean. 2006. "Serum Polychlorinated Biphenyl and Organochlorine Insecticide Concentrations in a Faroese Birth Cohort." Chemosphere 62 (7) (February): 1167-1182. doi:10.1016/ j.chemosphere.2005.06.063. http://dx.doi.org/10.1016/j.chemosphere.2005.06.063.

\section{Published Version}

doi:10.1016/j.chemosphere.2005.06.063

\section{Permanent link}

http://nrs.harvard.edu/urn-3:HUL.InstRepos:34786602

\section{Terms of Use}

This article was downloaded from Harvard University's DASH repository, and is made available under the terms and conditions applicable to Other Posted Material, as set forth at http:// nrs.harvard.edu/urn-3:HUL.InstRepos:dash.current.terms-of-use\#LAA

\section{Share Your Story}

The Harvard community has made this article openly available.

Please share how this access benefits you. Submit a story. 


\title{
Concentrations of polybrominated diphenyl ethers, polychlorinated biphenyls, and polycholobiphenylols in serum from pregnant Faroese women and their children 7 years later
}

\author{
Britta Fängström*, Lotta Hovander, Anders Bignert ${ }^{1}$, Ioannis Athanassiadis, Linda Linderholm, \\ Philippe Grandjean ${ }^{2,3}$, Pál Weihe ${ }^{3,4}$, and Åke Bergman \\ Department of Environmental Chemistry, Stockholm University, \\ SE-106 91 Stockholm, Sweden; \\ ${ }^{1}$ Contaminant Research Group, Swedish Museum of Natural History, \\ SE-104 05 Stockholm, Sweden; \\ 2 Institute of Public Health, University of Southern Denmark, DK-5000 Odense, Denmark; \\ ${ }^{3}$ Department of Environmental Health, Harvard School of Public Health, \\ Boston, MA 02215, USA; \\ ${ }^{4}$ Faroese Hospital System, FR-100 Tórshavn, Faroe Islands
}

\begin{abstract}
The objective of this study was to assess blood concentrations of polybrominated diphenyl ethers (PBDEs) and polychlorinated biphenyls (PCBs), and their polychlorobiphenylol (OH-PCB) metabolites in humans with a high seafood intake. Samples were obtained from pregnant women in the Faroe Islands in 19941995 and from their children at 7 years of age to examine maternal transfer of the compounds to their child, age-dependent metabolism, and temporal changes. Maternal serum was dominated by 2,2',4,4'tetrabromodiphenyl ether (BDE-47), while 2,2',4,4',5,5'-hexabromodiphenyl ether (BDE-153) prevailed in the children's serum seven years later. DecaBDE was present in both mothers and children up to 3 and $6 \mathrm{ng} / \mathrm{g}$ lipid weight, respectively. The $\mathrm{\Sigma} \mathrm{PCB}$ concentration in the children averaged about $60 \%$ of the concentrations in their mothers, with median levels for both above $1 \mu \mathrm{g} / \mathrm{g}$ lipid weight and with similar PCB congener patterns. $5 \mathrm{OH}-\mathrm{PCB}$ serum concentrations from the mothers and their children showed ranges of 1.8-36 ng/g wet weight (w.w.) and 0.49-22 ng/g w.w., respectively, with all OH-PCB congener concentrations being lower in the children, except for 2,3,3',4',5-pentachloro-4-biphenylol (4-OHCB107). Children at 7 years of age are exposed to PCBs at levels only slightly below those of their mothers, and the increased 4-OH-CB-107 concentrations in children could be due to age-related differences in PCB metabolism. The PBDE concentrations were similar in both mothers and their children. The main persistent organic pollutant concentrations in the children are most probably due to other environmental exposure than maternal transfer.
\end{abstract}

*Corresponding author: britta.fangstrom@mk.su.se 


\section{Introduction}

Environmental pollutants have been of concern, since the early demonstration four decades ago that some organochlorine pesticides and polychlorinated biphenyls (PCBs) had obvious effects in wildlife in and around the Baltic Sea and the Great Lakes $(1,2)$. Later on, wildlife and humans in the Arctic and sub-Arctic regions came into focus, because they are highly exposed to persistent organic pollutants (POPs) (3). Hence, epidemiology studies have been carried out in populations in northern communities that depend on seafood that causes increased methylmercury and PCB exposures (4-7).

The present study focuses on a birth cohort in the Faroe Islands, a community of about 45000 inhabitants located between Shetland and Iceland. In addition to large-scale fishing, the Faroese conduct occasional subsistence whaling, which provides pilot whale meat and blubber for local distribution. In this fairly homogeneous community, dietary habits depend on local availability and personal preferences, rather than socioeconomic factors. In 2000-2001 a questionnaire study of Faroese adults showed an average daily consumption of $40 \mathrm{~g}$ fish, $1.5 \mathrm{~g}$ whale muscle, and $0.6 \mathrm{~g}$ of blubber (7). This is a significantly decrease since 1981-1982 where the average daily consumption were $72 \mathrm{~g}$ of fish, $12 \mathrm{~g}$ of whale muscle and $7 \mathrm{~g}$ of blubber (8). Despite this significant change in dietary habits, no significant reduction in concentrations of persistent PCB congeners has been observed in serum samples taken in 1994-1995 and 20002001 (7). The aim of the present study was to analyze serum samples to assess the internal exposure to polybrominated diphenyl ethers (PBDEs) and hydroxylated PCB metabolites $(\mathrm{OH}-$ PCBs) and their association with PCB concentrations. We analyzed samples obtained from women during pregnancy in 1994/1995 and from their children at 7 years of age (2001/2002) to explore how the concentration levels in the child are depended on the maternal levels and the extent to which congener differences of PBDEs and OH-PCBs in mothers and children are related to differences in age and to temporal trends.

PBDEs have caused increasing worldwide contamination over the last decade (9-12), with particularly high PBDE concentrations in the U.S. $(13,14)$. We recently reported increasing concentrations of PBDEs in human milk from the Faroe Islands (10). To date, the most abundant PBDE congener has been 2,2',4,4'-tetrabromodiphenyl ether (BDE-47), but more recently a hexaBDE often has been observed to occurs in similarly high concentrations or even higher in humans $(10,15)$. A recent study reported similar concentrations of BDE-47 and decaBDE (BDE209) in subjects with background exposure in Sweden (16). These observations were considered when selecting PBDE congeners for analysis, as was the need to obtain new data on BDE-209.

Given the well-documented high PCB exposure level in the Faroes (4-7), a parallel focus of the present study was the $\mathrm{OH}-\mathrm{PCBs}$, which are $\mathrm{PCB}$ metabolites with a strong retention in human blood $(17,18)$. Depending on the structure, $\mathrm{OH}-\mathrm{PCB}$ s bind to the thyroxine transport protein, transthyretin (TTR) (19-21). These metabolites have been found at concentration levels of 10$30 \%$ of the PCB concentrations in blood (22-28). The substances selected for analysis are metabolites of the persistent PCB congeners CB-105, CB-118, CB-138, CB-153 and CB-187 (18). With a continuous supply of parent PCB congeners, concentrations of OH-PCB congeners would be expected to be fairly stable in the blood. The OH-PCBs are easily transferred to the foetus, via the placenta, possibly due to their slight acidic and/or protein binding characteristics $(24,29)$. Their transfer is in fact more efficient than of PCBs. 


\section{Material and Methods}

Cohort and samples: A cohort of 182 singleton term births was generated from consecutive births over a 12-month period from 1994 to 1995 at the National Hospital in Tórshavn, Faroe Islands $(30,31)$. This cohort represents $64 \%$ of the 293 births that occurred during this period. Only a few women did not consent to participate, and incomplete sampling was mainly due to surgical intervention or logistic problems in the busy ward. Maternal serum was obtained from 175 of the women, in connection with the last routine consultation in pregnancy week 34 . The pregnant women are referred to as "mothers" below. In 2000-2001, the children underwent detailed clinical examinations at 7 years of age, and serum samples were obtained from most of them. The serum lipid content was determined from enzymatic measurements of cholesterol and triglycerides (32). On the basis of determinations of PCB in maternal serum already carried out $(30,31)$, a subgroup of mother and child pairs was selected for the purposes of the present study. For the sake of study efficiency, samples were selected that represented the widest possible ranges of POP concentrations. Assuming that samples with extreme PCB concentrations would provide the greatest insight into relative concentrations of the substances analyzed, we chose a weighted selection of samples. We selected equal numbers of subjects with the highest and the lowest PCB concentrations and half as many with PCB concentrations close to the average. Although the median level would be appropriate, the distribution would therefore not be representative for the Faroese population in general. The final numbers were slightly different from the original plan, since some children did not participate in the clinical examinations, at age 7 years or did not provide a blood sample or because some specimens had already been exhausted by other analyses. Under the circumstances available, we were able to secure serum (1-3 mL) from 57 mothers and 42 children (boys $n=21$ and girls $n=21$ ). Where 41 samples were pairs i.e. mothers and children. The cohort study was approved by the ethical review committee for the Faroe Islands, and written informed consent was obtained from all parents.

Chemicals: The individual PBDE congeners (numbered according to Ballschmiter et al 1993 (33)) BDE-47, BDE-77, BDE-99, BDE-100, BDE-153, BDE-154, and BDE-209 were synthesized in-house $(34,35)$. The individual PCB congeners similarly numbered (33) $\mathrm{CB}-105$, CB-101, CB-118, CB-128; CB-129, CB-138, CB-146, CB-153, CB-156, CB-157, CB-170, CB172, CB-177, CB-180, CB-183, CB-187, CB-194, CB-195, CB-196, CB-200 and CB-207 were either synthesized in-house $(36,37)$ or purchased from Larodan Fine Chemicals $A B$, Malmö, Sweden. The hydroxylated PCB reference standards: 4-OH-CB107, 3'-OH-CB138, 4-OH$\mathrm{CB} 146$, 3-OH-CB153, 4-OH-CB187 and 4-OH-CB193 were synthesized as described by Bergman and co-workers (38) and abbreviated according to Letcher et al (18). All solvents were of pesticide quality. 2-Propanol from AnalaR (BDH laboratory supplies pool, England) and methyl tert-butyl ether (HPLC-grade; Rathburn, Walkerburn, U.K.) were glass-distilled prior to use. Silica gel $(<0.063 \mathrm{~mm})$ was purchased from Merck (Darmstadt, Germany) and activated at $300^{\circ} \mathrm{C}$ overnight, before it was used. Diazomethane was prepared from $N$-methyl- $N$-nitroso- $P$ toluenesulfonamide (Diazald), which was obtained from Sigma-Aldrich (Steinheim, Germany) (39).

Instruments: The PBDE analysis was performed by gas chromatography/mass spectrometry (GC/MS) utilising a Finnigan TSQ 700 instrument (ThermoFinnigan, Bremen, Germany) connected to a Varian 3400 gas chromatograph equipped with a CTC A200S autosampler. The transfer line temperature was set to $290^{\circ} \mathrm{C}$ and the ion source temperature maintained at $200^{\circ} \mathrm{C}$. Injections were made on a septum-equipped temperature-programmable injector (SPI) fitted with a high-performance insert directly connected to a DB-5 HT capillary column (15 m x $0.25 \mathrm{~mm}$ i.d., $0.1 \mu \mathrm{m}$ film thickness; J\&W Scientific) with helium as the carrier gas, at a head pressure of 3 psi. The injector was temperature-programmed from $60^{\circ} \mathrm{C}$ to $320^{\circ} \mathrm{C}$ at $150^{\circ} \mathrm{C} / \mathrm{min}$, and the oven 
from $80^{\circ} \mathrm{C}(1 \mathrm{~min})$ to $300^{\circ} \mathrm{C}(16 \mathrm{~min})$ at $15^{\circ} \mathrm{C} / \mathrm{min}$. The PBDE congeners were analyzed with selected ion monitoring (SIM) by scanning for the negative bromide ion (isotopes $\mathrm{m} / \mathrm{z} 79$ and 81 ), formed by electron capture reactions at chemical ionization (ECNI) with methane (5.0, AGA, Stockholm, Sweden) as the electron thermalization buffer gas at 5.6 Torr and a primary electron energy of $70 \mathrm{eV}$. All chromatographic data were collected, analyzed, and quantified using the proprietary ICIS2 software from Thermofinnigan.

The PCB and OH-PCB analysis were performed on a Varian 3400 gas chromatograph, equipped with a Varian 8200 autosampler, an electron capture detector (ECD), and a splitsplitless injector operated in the splitless mode. Hydrogen was used as the carrier gas and nitrogen as the make-up gas. A CP-Sil-8-column $(25 \mathrm{~m} \mathrm{x} 0.15 \mathrm{~mm}$ i.d. and $0.12 \mu \mathrm{m}$ film thickness Chrompack, EA Middleburg, The Netherlands) was used. For the PCB analysis the column temperature was $80^{\circ} \mathrm{C}(1 \mathrm{~min})$ to $300^{\circ} \mathrm{C}(5 \mathrm{~min})$ at $20^{\circ} \mathrm{C} / \mathrm{min}$, and for the $\mathrm{OH}-\mathrm{PCB}$ analysis the column temperature was $80^{\circ} \mathrm{C}(1 \mathrm{~min})$ to $200^{\circ} \mathrm{C}(1 \mathrm{~min})$ at $50^{\circ} \mathrm{C} / \mathrm{min}$ and then to $230^{\circ} \mathrm{C}$ at $1{ }^{\circ} \mathrm{C} / \mathrm{min}$ and finally to $330^{\circ} \mathrm{C}(2 \mathrm{~min})$ at $50^{\circ} \mathrm{C} / \mathrm{min}$. The injector temperature was $280^{\circ} \mathrm{C}$ and the detector temperature was $360^{\circ} \mathrm{C}$. The data were collected using a PC-based ELDS Pro v2.0 system (Chromatographic Data System AB, Stockholm, Sweden).

A table centrifuge (Wifug Ltd, Parry Lane, Bradford, England) operated at $3000 \mathrm{rpm}$ was used to promote efficient phase separation.

Cleanup procedure: The extraction and cleanup procedure of the serum has been described in detail by Hovander and co-workers (40). The surrogate standards (SSs), BDE-77 (0.2 ng), CB200 (2 ng) and 4-OH-CB193 (1 ng), were added to 1-3 $\mathrm{mL}$ of serum prior to extraction. The extracts were evaporated and resolved in hexane. The neutral and phenolic substances were separated with potassium hydroxide $(0.5 \mathrm{M}$ in $50 \%$ ethanol) and hexane partitioning $(40)$. The bulk of lipid in the neutral fraction was removed with concentrated sulfuric acid treatment. Additional cleanup was then performed with two silica/sulfuric acid columns $(0.9 \mathrm{~g}$ and $0.5 \mathrm{~g}$ respectively) (40). The silica gel column was always washed prior to sample application with the same solvent as the analytes were to be eluted with. The neutral fraction was fractionated on a column of activated silica gel $(0.7 \mathrm{~g})$. Most of the PCB congener and major traditional organochlorine pesticide interferences were eluted with hexane $(3 \mathrm{~mL})$ and the PBDEs were eluted with hexane/dichloromethane $(1: 1,8 \mathrm{~mL})$. The solvent in the PBDE fraction were changed to hexane and reduced to $50 \mu \mathrm{L}$ prior GC/MS analysis. The PCBs were analyzed on GC/ECD before the PBDE fraction. The halogenated phenolic compounds were derivatized with diazomethane, and the lipids in the methylated phenolic fraction were removed with concentrated sulfuric acid followed by a column with silica/sulfuric acid, as described elsewhere (40). All samples were protected from daylight during handling and storage to prevent any photochemical degradation of the brominated compounds to be analyzed.

Analysis: Six PBDE congeners, BDE-47, 99,100, 153, 154 and 209 were analyzed with GC/MS (ECNI), as specified above, and quantified with the SS, BDE-77. BDE-154 could not be quantified alone due to co-elution of the 2,2',4,4',5,5'-hexabromobiphenyl (BB-153) known to be present in, for example, human serum samples $(12,41)$. Eighteen PCB congeners, CB-105, 118, $128 ; 129,138,146,153,156,157,170,172,177,180,183,187,194,195$ and 196 were analyzed by GC/ECD, as described above, and quantified with CB-200 as the SS. CB-207 was used as a recovery standard for CB-200. 4-OH-CB107, 3'-OH-CB138, 4-OH-CB146, 3-OH-CB153, and 4$\mathrm{OH}-\mathrm{CB} 187$ were analyzed by GC/ECD (c.f. above) and quantified using 4-OH-CB193 as the SS.

Procedure solvent blank samples representing every seventh sample were cleaned up and analyzed in the same way as the other samples. Limits of quantification (LOQ) for PBDEs were defined in direct relation to the amount of interference of PBDEs in the blank samples. The PBDEs in the samples had to be 3 times the concentration of the PBDE in the blank to be 
considered for quantification. The average blank sample amount has been subtracted from the results. Laboratory Reference Material (LRM) was run in parallel to the analyzed samples. The overall recoveries and standard deviations (SD) of the surrogate standards were $93 \pm 18 \%$ for BDE-77, $105 \pm 17 \%$ for CB-200, and $88 \pm 12 \%$ for $4-\mathrm{OH}-\mathrm{CB}-193$.

Statistical analysis: The distributions of the analyzed contaminant concentrations are, as expected (see e.g. ref 42), markedly and significantly skewed to the right. Therefore, medians have been used to represent central values of the concentrations. Results below the LOQ have been substituted using a regression technique, based on ranked concentrations (43), to achieve unbiased medians, since sometimes $50 \%$ or more of the values are below the LOQ. Linear regression analysis and the nonparametric Mann-Kendall trend test $(44,45)$ was used to investigate the relations between $\mathrm{OH}-\mathrm{PCBs}$ and their parent $\mathrm{PCB}$ congeners and between concentrations in mothers and their children.

\section{Results}

Median and range concentrations are presented for the PBDEs, PCBs, and OH-PCBs in Tables 1-3 as determined in the pregnant women and their children at the age of 7 years. The concentrations are given both on a wet weight or lipid weight basis (ng/g) and a molar basis to promote direct comparisons between analytes with substantial differences in molecular weight. The median lipid content of the serum in the mothers was 1.6 times the level in the serum from the children, and serum lipid concentrations in mother-child pairs showed a clear correlation $\left(\mathrm{r}^{2}=0.20, \mathrm{p}<0.003\right)$.

Data on the five major PBDE congeners and BDE-154/BB-153 concentrations in serum are presented in Table 1. The maternal PBDE concentrations were notably higher for congener BDE47, while the children's results showed higher concentrations of BDE-153. No association was found between PBDE congener concentrations in the pregnant women and their children at 7 years of age.

Quantitative data for 18 PCB congeners, with one pair of co-eluting congeners, in maternal and child serum are presented in Table 2. The highest concentrations were observed for CB-153, CB-138, and CB-180, in decreasing order, both in the mothers and in the children. Regression analyses of the paired serum samples from mother and child $(n=41)$ showed that the concentrations in the children are associated with the concentrations in their mothers, prior to delivery.

The five OH-PCB congeners analyzed are similarly presented in Table 3. For the 41 complete mother-child pairs, concentrations of $\mathrm{OH}-\mathrm{PCBs}$ were also correlated. Both the PCB and $\mathrm{OH}-\mathrm{PCB}$ associations were statistically significant ( $\mathrm{p}<0.05$, in most cases $\mathrm{p}<0.001$ ). In general, about $20-35 \%$ of the variation in the children's serum concentrations of these analytes can be explained by the concentration in their mother's serum, 7 years earlier.

As shown in Table 4, the concentrations of OH-PCBs were also associated with concentrations of their corresponding parent PCB congener. The correlations were studied using both linear regression analysis and the Mann-Kendall trend analysis (to avoid undue influence of extreme values) on the whole data set $(n=96-99)$. The result showed significant correlations, $\mathrm{p}<0.001$, except for 4-OH-CB107 vs CB-105 at $\mathrm{p}=0.02$, linear regression. 
Table 1. PBDE congener concentrations (in ng/g lipid weight (1.w.) and in pmol/g l.w.) median and range, as determined in serum from Faroese mothers sampled in 1994/1995 and children sampled in 2001/2002.

\begin{tabular}{|c|c|c|c|c|c|c|c|}
\hline & \multicolumn{3}{|c|}{ Mothers $(\mathrm{n}=57)^{\mathrm{a}}$} & \multicolumn{3}{|c|}{ Children $(\mathrm{n}=42)^{\mathrm{a}}$} & \multirow[b]{2}{*}{$\begin{array}{c}\mathrm{LOQ} \\
\mathrm{pmol} / \mathrm{g}\end{array}$} \\
\hline & $\begin{array}{c}\text { median } \\
\text { ng/g l.w. }\end{array}$ & $\begin{array}{c}\text { median } \\
\text { pmol/g l.w. }\end{array}$ & $\begin{array}{c}\text { range } \\
\mathrm{pmol} / \mathrm{g} \text { l.w }\end{array}$ & $\begin{array}{l}\text { median } \\
\text { ng/g l.w. }\end{array}$ & $\begin{array}{c}\text { median } \\
\mathrm{pmol} / \mathrm{g} \text { l.w. }\end{array}$ & $\begin{array}{c}\text { range } \\
\mathrm{pmol} / \mathrm{g} \text { l.w }\end{array}$ & \\
\hline BDE-47 & 1.3 & 2.7 & $<$ LOQ-23 $(17)^{\mathrm{b}}$ & 0.87 & 1.8 & $<$ LOQ-68 $(22)^{\mathrm{b}}$ & 1 \\
\hline BDE-99 & 0.33 & 0.59 & $<$ LOQ-8.2 $(9)^{\mathrm{b}}$ & 0.47 & 0.83 & $<$ LOQ-35 $(16)^{\mathrm{b}}$ & 0.2 \\
\hline BDE-100 & 0.51 & 0.90 & $<$ LOQ-4.1 $(21)^{\mathrm{b}}$ & 0.14 & $0.24^{\mathrm{c}}$ & $<$ LOQ-14 $(29)^{\mathrm{b}}$ & 0.5 \\
\hline BDE-153 & 1.0 & 1.5 & $0.40-11$ & 2.5 & 3.9 & $1.2-15$ & 0.4 \\
\hline BDE-209 & 0.77 & 0.80 & $<$ LOQ-3.8 $(9)^{\mathrm{b}}$ & 1.0 & 1.0 & $<$ LOQ-6.4 (18) ${ }^{\mathrm{b}}$ & 0.3 \\
\hline BDE-154/BB-153 ${ }^{\mathrm{d}}$ & 1.4 & 2.1 & $0.38-15$ & 0.74 & 1.2 & $<$ LOQ-6.7 (8) & 0.3 \\
\hline
\end{tabular}

${ }^{a}$ Lipid concentrations in mother serum median: $0.89 \%$ and range $0.53-1.4 \%$ and in serum from the children median $0.56 \%$ and range $0.40-0.81 \%$.

${ }^{\mathrm{b}}$ Number of samples below the limit or quantification (LOQ) are given in the parenthesis. ${ }^{\mathrm{c}}$ The estimated median is below the LOQ, since more than $50 \%$ of the observations are below the LOQ and were substituted by estimated concentrations using a regression technique, based on ranked concentrations (43), to achieve unbiased medians. ${ }^{\mathrm{d}}$ The corresponding data are given for the coeluting BDE-154/BB-153. 
Table 2. PCB congener concentrations (in ng/g lipid weight (l.w.) and in pmol/g l.w.) median and range, as determined in serum from Faroese mothers sampled in 1994/1995 and children sampled in 2001/2002 are given.

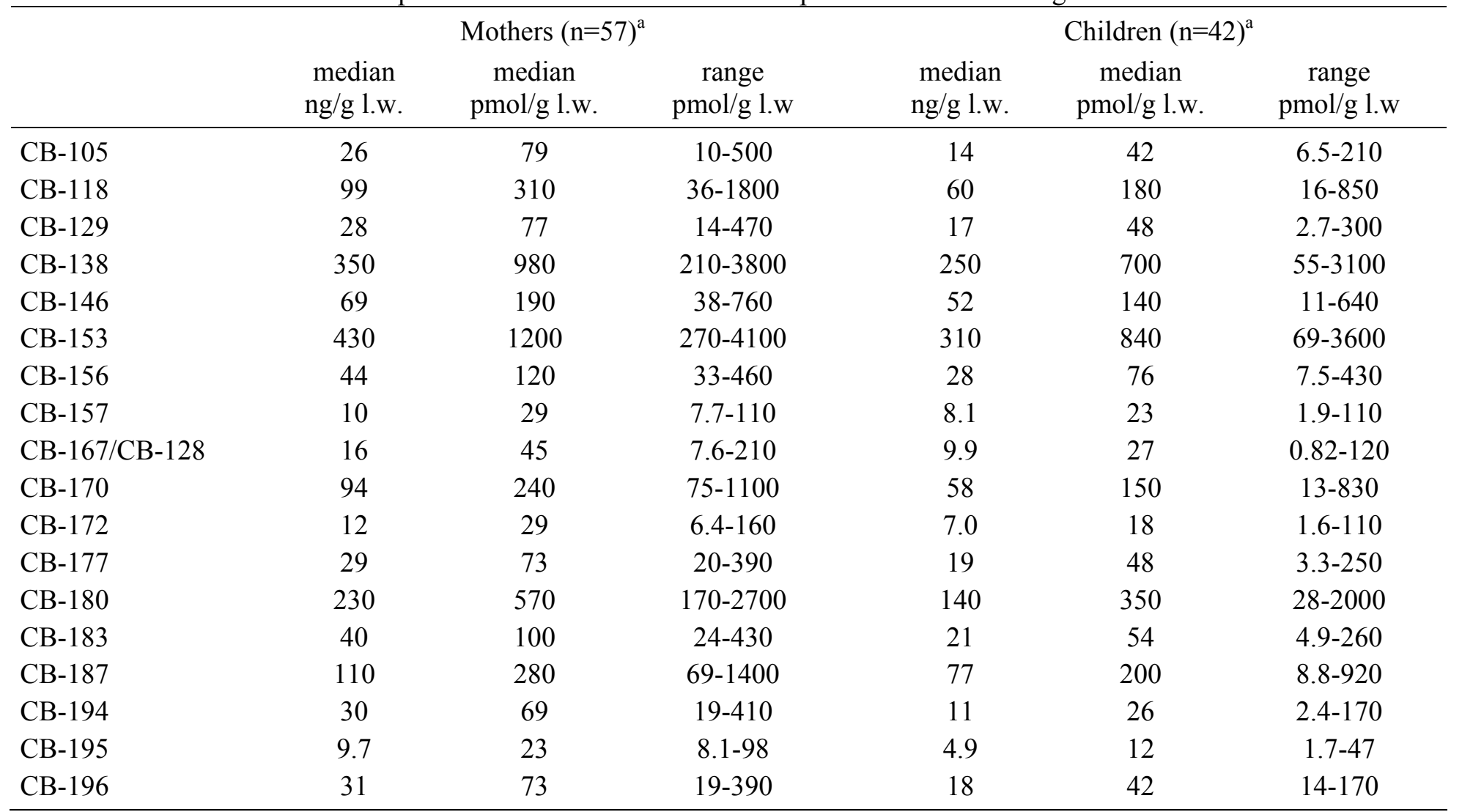

${ }^{\mathrm{a}}$ Lipid concentrations in mother serum: median $0.89 \%$ and range $0.53-1.4 \%$ and in serum from the children median $0.56 \%$, and range $0.40-0.81 \%$. 
Table 3. OH-PCB congener median concentrations (in ng/g wet weight (w.w.), ng/g lipid weight (l.w.) and in pmol/g l.w.) and ranges (in pmol/g l.w.) as determined in Faroese mothers sampled in 1994/1995 and children sampled in 2001/2002.

\begin{tabular}{|c|c|c|c|c|c|c|c|c|}
\hline & \multicolumn{4}{|c|}{ Mothers $(\mathrm{n}=57)^{\mathrm{a}}$} & \multicolumn{4}{|c|}{ Children $(\mathrm{n}=42)^{\mathrm{a}}$} \\
\hline & $\begin{array}{c}\text { median } \\
\text { ng/g w.w. }\end{array}$ & $\begin{array}{l}\text { median } \\
\text { ng/g l.w. }\end{array}$ & $\begin{array}{c}\text { median } \\
\mathrm{pmol} / \mathrm{g} \text { l.w. }\end{array}$ & $\begin{array}{c}\text { range } \\
\mathrm{pmol} / \mathrm{g} \text { l.w }\end{array}$ & $\begin{array}{c}\text { median } \\
\text { ng/g W.W. }\end{array}$ & $\begin{array}{l}\text { median } \\
\text { ng/g l.w. }\end{array}$ & $\begin{array}{c}\text { median } \\
\mathrm{pmol} / \mathrm{g} \text { l.w. }\end{array}$ & $\begin{array}{c}\text { range } \\
\mathrm{pmol} / \mathrm{g} \text { l.w }\end{array}$ \\
\hline 4-OH-CB107 & 0.47 & 54 & 160 & $16-870$ & 0.71 & 130 & 380 & $25-1700$ \\
\hline 4-OH-CB146 & 0.79 & 88 & 230 & $58-940$ & 0.38 & 68 & 180 & $13-1300$ \\
\hline 3-OH-CB153 & 0.29 & 31 & 83 & $14-610$ & 0.12 & 23 & 60 & $4.2-280$ \\
\hline 3'-OH-CB138 & 0.33 & 33 & 88 & $20-680$ & 0.16 & 31 & 82 & $4.8-350$ \\
\hline 4-OH-CB187 & 1.50 & 150 & 370 & $93-1500$ & 0.57 & 99 & 240 & $28-1100$ \\
\hline
\end{tabular}

${ }^{\mathrm{a}}$ Lipid concentrations in mother serum: median $0.89 \%$ and range $0.53-1.4 \%$ and in serum from the children median $0.56 \%$ and range 0.40 $0.81 \%$.

Table 4. Relations between the retained OH-PCB metabolite and their suggested precursor PCB congener $\left(n=\right.$ number of samples, $r^{2}=$ coefficient of determination with corresponding $p$-value, tao=Mann-kendall's tao with corresponding p-value).

\begin{tabular}{lllllll}
\hline OH-PCB metabolite & Parent PCB congener & $\mathrm{n}$ & $\mathrm{p}$-value & $\mathrm{r}^{2}$ & tao & $\mathrm{p}<$ \\
\hline 4-OH-CB107 & CB-105 & 99 & $<0.02$ & 0.05 & 0.29 & 0.001 \\
4-OH-CB107 & CB-118 & 99 & $<0.001$ & 0.13 & 0.39 & 0.001 \\
3-OH-CB138 & CB-138 & 98 & $<0.001$ & 0.50 & 0.60 & 0.001 \\
4-OH-CB146 & CB-138 & 99 & $<0.001$ & 0.58 & 0.71 & 0.001 \\
4-OH-CB146 & CB-153 & 99 & $<0.001$ & 0.58 & 0.70 & 0.001 \\
3'-OH-CB153 & CB-153 & 96 & $<0.001$ & 0.55 & 0.61 & 0.001 \\
4-OH-CB187 & CB-187 & 99 & $<0.001$ & 0.65 & 0.67 & 0.001 \\
\hline
\end{tabular}




\section{Discussion}

The relative PBDE congener pattern differed between the maternal serum, which was dominated by BDE-47 and the children's serum, in which BDE-153 prevailed 7 years later. BDE-209 was present in both maternal and children serum. The $\Sigma$ PCB concentration in the children averaged about $60 \%$ of the concentrations in their mothers, and the PCB congener patterns were identical. It could be stated that about $20-35 \%$ of the PCB concentrations in the children were of maternal origin. No such relation was possible for the PBDEs. However, although $\Sigma$ OH-PCB serum concentrations from the mothers and their children were similar, all OH-PCB congener showed lower concentrations in the children, except for 4-OH-CB107. These results add substantially to the current knowledge on POP exposures in remote societies.

The major strength of this study is that 99 samples of maternal serum $(n=57)$ and serum from their children at 7 years of age $(n=42)$, were analyzed for PBDEs, PCBs, and OH-PCBs (Tables 1-3). Among those analytes, the PBDEs and the OH-PCBs are of particular interest due to the limited availability of such data, particularly in humans remote from industrial sources. Within the samples available for analysis, 41 were paired samples, i.e., from the pregnant mothers and their children, where the maternal samples were obtained 7 years prior to the samples from their children. The PBDE concentrations are reported both on a weight basis and on a molar basis, since the large molecular weight span for PBDE congeners has to be accounted for, e.g., when concentrations of BDE-47 and BDE-209 are compared (cf. Table 1). Since most studies are still using weight basis to present their results the concentrations are given also on a weight basis. Limited emphasis is placed on the sum of PBDE, PCB or OH-PCB congeners, since a summary measure is a poor way to represent exposures to a heterogeneous class of environmental chemicals.

The findings are in agreement with previous research where concentrations of the PBDEs are increasing in the Faroese human milk (10) and are also present in Faroese wildlife, e.g. pilot whale and fulmars $(46,47)$. Both these two species are part of the traditional diet for the Faroe Island population, although the PBDE concentrations in the fulmars are very low while the pilot whale blubber have shown to contain concentrations between 1000 and $3000 \mathrm{ng} / \mathrm{g}$ lipid weight (1.w.) $(46,47)$. The median $\Sigma$ PBDE maternal serum concentration is similar as seen in the human milk with the sum of the same five PBDE congeners at median levels at $4 \mathrm{ng} / \mathrm{g} 1 . \mathrm{w}$, all of these samples originating from the pregnant women examined in 1994 (10). The median $\Sigma$ PBDE (BDE-47, 99, 100, 153, and 209) concentrations in maternal and children's serum were similar, 4.0 and $5.0 \mathrm{ng} / \mathrm{g} \mathrm{l.w}$. respectively. This finding is in accordance with a recent age-related Norwegian study (48). Further, no significant correlation was found between paired PBDE concentrations in the mothers and their children. The result differs from the findings in regard to PCB and OH-PCB concentrations. This might be due to low PBDE concentrations and relatively high PCB concentrations in the mothers during nursing (1994-1995). However, these comparisons are complicated by the different times of sampling, which were 7 years apart.

In regard to PBDE congener pattern differences, the most obvious difference is the high BDE-153 concentration in the children compared to their mothers having BDE-47 as the dominating PBDE congener. This finding may be related to changes in the environmental accumulation pattern over time, but it could also be affected by temporal changes. The notion of a temporal change is supported by analyses of human milk from the Faroe Islands, where BDE-153 showed a dramatic increase between 1994-1995 and 1998-1999 (10). Yet, there is no definite explanation for this change in the accumulation profile of PBDEs. A possibility could be the metabolism of BDE-209 leading to the formation of BDE-153, or the higher persistence of BDE153 than of the lower brominted congener as BDE-47.

Other differences between the mothers and children are the lower BDE-47 and BDE-100 concentrations in the children (Table 1). This result may indicate that sources of lower brominated diphenyl ethers are decreasing, since the maternal serum samples were sampled 
7 years prior to the children's serum, although other factors, such as age-related metabolism, may also play a role. The BDE-209 seems to be higher in the children than in the mothers, but this difference is very small, although in accordance with the reported occurrence of BDE-209 in human milk (10). The accumulation of BDE-209 concentration is probably influenced by the short apparent half-life of 15 days in human blood (49). However, a continuous BDE-209 concentration in the blood may conceivably lead to a slow transfer to the lipids through partitioning, and BDE-209 in the lipid phase may well have a much longer half-life. Hence BDE209 can be characterised as both a persistent and a semipersistent compound. The source and origin of BDE-209 in the Faroe Islands is still unknown, and numbers of PBDE reports including BDE-209 from the Artic environment are still limited. This is most probably due to low concentrations in combination with difficulties in the analytical procedure for BDE-209 due to contamination problems. However, BDE-209 has recently been detected in low concentrations in plasma from polar bear and in glaucous gulls (50).

The PCB concentrations are in agreement with previous reports from the Faroese population $(25,31)$, and these PCB concentrations are high compared to international data on human levels of PCBs (51). The concentrations are comparable to serum levels of PCBs in Eastern Slovakia, where a hotspot is located (52). Even though there is 7 years between the sampling occasions in the present study and a difference in the ages of the blood donors (mothers and children), a very similar congener pattern is observed in maternal and children's serum, as indicated by calculations of concentrations relative to those of CB-138 in the mothers and in the children (Table 2). However, PCB congener concentrations are on average about $40 \%$ lower in the children than in the mothers without taking into account the lower serum lipid levels in the children. The strong correlations between the PCBs in the mothers and in the children suggest that about $20-35 \%$ of the variability of the children's serum PCB concentrations is of maternal origin. This observation is in accordance to those obtained from another Faroese cohort, where serum PCB concentrations at 7 years of age were significantly associated with the duration of nursing (53). The association between PCB serum concentration in mothers and children may therefore be due to maternal transfer during pregnancy and nursing, but other factors, such as similarity of their diet (mother vs their own child), and genetic determinants of metabolic capacity also need to be considered. In regard to the latter, very little information is available, but clues may be obtained from examination of $\mathrm{OH}-\mathrm{PCB}$ concentration patterns.

The OH-PCB metabolite concentration in the Faroe Island mothers and children are within the range of the levels elsewhere in the world (c.f. Table 3 and 5). The five OH-PCB congeners present as the major hydroxylated PCB metabolites in serum show concentrations in a similar range or higher than many of the PCB congeners analyzed (Table 2 and 3). Although the $\mathrm{OH}-$ PCBs are lipophilic compounds when neutral, the comparison is made on a fresh weight basis, since the OH-PCBs are poorly transferred to the lipid phase (10). The OH-PCBs are rather associated to the fresh weight since these PCB metabolites bind to the thyroxine transporting protein, transthyretin (TTR) $(20,54)$. Endocrine-related effects that have been reported for $\mathrm{OH}-$ PCBs, make them particularly interesting from a dose/response perspective (55-57).

Comparisons of the OH-PCB congener patterns in the mothers and the children show that all, but one of the congeners quantified has a lower median concentration in the children (Table 3). 4-OH-CB107, a metabolite originating from CB-105 and CB-118, has a higher median in the children than in the mothers and higher than that observed in the highest blubber consumption group in a previous study of mothers from the Faroe Islands (25). 4-OH-CB107 concentrations have been reported to fluctuate, but reasons for this variability are unknown. High concentrations of 4-OH-CB107 in the children may indicate a difference in the enzymatic capability to transform the pentaCB precursors (CB-105 and CB-118). In relation to their body mass, children have a larger liver size, which may compensate for possible immaturity of drug-metabolizing enzymes (58), and the relative impact on parent PCBs and OH-PCBs therefore does not seem to provide 
any explanation for the deviating results on 4-OH-CB-107 in the mothers and their children. However, this OH-PCB congener is thought to have a shorter half-life than the higher chlorinated congeners, as suggested by a study in rats, in which 4-OH-CB107 and 4-OH-CB187 had apparent half-lives of 3.8 and 15 days, respectively (59). The short half-lives for OH-PCB congeners (59) also indicate that the $\mathrm{OH}-\mathrm{PCB}$ concentrations present in the children are due to metabolism in the child rather that fetal transfer. Although significant correlations between the five OH-PCBs and their precursors (Table 4) emphasize the origin of these metabolites, the lowest correlation was observed for the 4-OH-CB107 and its precursors CB-105 and CB-118. This observation may be due to the greater instability of concentration levels for congeners with a shorter half-life. However, correlations may be obtained between the OH-PCB congeners and most of the PCB congeners, because of the close association between the latter. Thus, an observational study like the present one does not allow modelling of the individual $\mathrm{OH}-\mathrm{PCB}$ concentrations on the PCB concentration data from only one set of results.

The exposure assessment presented in this study shows that the remote and apparently pristine Faroese environment is subject to exposure to POPs and their metabolites. The PBDE congener pattern seems to be shifting, from lower to higher brominated congeners and the concentrations of PCBs and OH-PCB continue to be at a level considered high in international comparisons. The traditional seafood diet is probably the main source for POP exposure at the Faroe Islands. Although dietary change may be advantageous under such circumstances, the food contamination problems are augmented in populations, such as the Faroese, that depend on seafood high in the food chains. The unexpected findings on certain POP congeners and relative differences between mothers and their children suggest that such populations may provide important clues to POP exposure and metabolism that may be of relevance elsewhere.

\section{Acknowledgement}

Maria Athanasiadou is highly appreciated for her contribution to this project. Financial support for the study has been given by grants from the EU R\&D programme, Anemone (QLK4-CT2001-00186). 
Table 5. Concentrations (ng/g lipid weight (1.w.))of 4-OH-CB107, 4-OH-CB146 and 4-OH-CB187 in human plasma samples from different geographical areas.

\begin{tabular}{|c|c|c|c|c|c|c|c|c|c|c|}
\hline \multirow[t]{2}{*}{ Country } & \multirow[t]{2}{*}{ Collection year } & & \multirow[b]{2}{*}{$\mathrm{N}$} & \multicolumn{2}{|c|}{$\begin{array}{c}\text { 4-OH-CB107 } \\
\text { ng/g l.w. }\end{array}$} & \multicolumn{2}{|c|}{$\begin{array}{c}\text { 4-OH-CB146 } \\
\text { ng/g l.w. }\end{array}$} & \multicolumn{2}{|c|}{$\begin{array}{c}\text { 4-OH-CB187 } \\
\text { ng/g l.w. }\end{array}$} & \multirow[b]{2}{*}{ Ref. } \\
\hline & & & & median & (range) & median & (range) & median & (range) & \\
\hline \multirow[t]{2}{*}{ Sweden } & \multirow[t]{2}{*}{1995} & Low $^{a}$ & 16 & 36 & $0-59$ & & & 41 & 4-72 & \multirow[t]{2}{*}{ (23) } \\
\hline & & High $^{b}$ & 16 & 81 & $28-480$ & & & 93 & $43-270$ & \\
\hline \multirow[t]{2}{*}{ Netherlands } & \multirow[t]{2}{*}{$1998-2000$} & Maternal & 51 & 10 & $0.8-38$ & 10 & $3-27$ & 20 & $7-49$ & \multirow[t]{2}{*}{ (24) } \\
\hline & & Cord & 51 & 14 & $4-350$ & 23 & $8-58$ & 38 & $17-69$ & \\
\hline \multirow[t]{2}{*}{ Faroe Islands $^{c}$} & \multirow[t]{2}{*}{ 1994-1995 } & Low $^{d}$ & 21 & 12 & $5.1-73$ & 23 & $9.8-170$ & 37 & $18-220$ & \multirow[t]{2}{*}{ (25) } \\
\hline & & High $^{\mathrm{e}}$ & 15 & 71 & $49-230$ & 120 & $3-270$ & 190 & $23-470$ & \\
\hline \multirow[t]{2}{*}{ Slovakia } & \multirow[t]{2}{*}{2001} & Stropkow/Svidnik & 178 & 26 & $0.9-84$ & 26 & $6.6-92$ & 57 & $15-260$ & \multirow[t]{2}{*}{ (60) } \\
\hline & & Michalovche & 141 & 63 & $3.8-1100$ & 74 & $6.7-1000$ & 140 & $11-2000$ & \\
\hline \multirow[t]{4}{*}{ Canada Quebec ${ }^{\mathrm{f}}$} & \multirow[t]{4}{*}{ 1993-1996 } & Cord plasma from & & & & & & & & \multirow[t]{4}{*}{ (61) } \\
\hline & & Nunavik, & 10 & 6 & $1.5-22$ & 18 & $2-67$ & 24 & $6.5-78$ & \\
\hline & & Lower North Shore, & 10 & 24 & $3-84$ & 40 & $8-250$ & 48 & $27-125$ & \\
\hline & & Southern Quebec & 10 & 5.5 & $1.5-22$ & 6 & $2-29$ & 14 & $5-48$ & \\
\hline
\end{tabular}

${ }^{\mathrm{a}}$ low $2,2^{\prime} 4,4^{\prime}, 5,5$-hexaCB concentration in the blood, ${ }^{\mathrm{b}}$ high2,2' $4,4^{\prime}, 5,5$-hexaCB concentration in the blood. ${ }^{\mathrm{c}} 10-90 \%$ percentile. ${ }^{\mathrm{d}}$ Low intake of pilot whale blubber. ${ }^{\mathrm{e}}$ High intake of pilot whale blubber. ${ }^{\mathrm{f}}$ Data normalized for lipid content of $0.2 \%$, according to Soechitram et al. 2004 (24), geometric mean (min-max). 


\section{References}

(1) Carson, R. Silent spring; Houghton Mifflin Co: Boston, 1962.

(2) WHO Global assessment of the state-of-the-science of endocrine disruptors; International Programme on Chemical Safety, WHO: Geneva, Switzerland, 2002.

(3) AMAP Arctic pollution 2002; AMAP: Oslo, 2002.

(4) Grandjean, P.; Weihe, P.; Needham, L. L.; Burse, V. W.; Patterson, D. G. Jr.; Sampson, E. J.; Jorgensen, P. J.; Vahter, M. Relation of a seafood diet to mercury, selenium, arsenic and polychlorinated biphenyl and other organochlorine concentrations in human milk. Environ. Res. 1995, 71, 29-38.

(5) Grandjean, P.; Weihe, P.; Burse, V. W.; Needham, L. L.; Storr-Hansen, E.; Heinzow, B.; Debes, F.; Murata, K.; Simonsen, H.; Ellefsen, P.; Budtz-Jorgensen, E.; Keiding, N.; White, R. F. Neurobehavioral deficits associated with PCB in 7-year-old children prenatally exposed to seafood neurotoxicants. Neurotoxicol. Teratol. 2001, 21, 305-317.

(6) Weihe, P.; Grandjean, P.; Debes, F.; White, R. Health implications for Faroe Islanders of heavy metals and PCBs from pilot whales. Sci. Total Environ. 1996, 186, 141-148.

(7) Weihe, P., Hoppe, H-W., and Grandjean, P., Sustained high concentrations of PCBs in Faroese pregnant women despite dietary intervention., Organohalogen Compounds 2003, 63, 389.

(8) Vestergaard, T.; Zachariassen, P. Dietary survey 1981-82. Fróðskaparrit 1987, 33, 5-18.

(9) Fürst, P., Organochlorine pesticides, dioxins, PCB and polybrominated biphenylethers in human milk from Germany in the course of time, Organohalogen Compounds 2001, 52, 185.

(10) Fängström, B.; Strid, A.; Grandjean, P.; Weihe, P.; Bergman, Å. A retrospective study of PBDEs and PCBs in human milk from the Faroe Islands. Environmental Health: A global Access science source 2005, 4.

(11) Meironyté, D.; Norén, K.; Bergman, A. Analysis of polybrominated diphenyl ethers in Swedish human milk. A time-related trend study, 1972-1997. Journal of Toxicology and Environmental Health, Part A 1999, 58, 329-341.

(12) Sjödin, A.; Jones, R. S.; Focant, J.-F.; Lapeza, C.; Wang, R. Y.; McGahee III, E. E.; Zhang, Y.; Turner, W. E.; Slazyk, B.; Needham, L. L.; Patterson Jr, D. G. Retrospective time-trend study of polybrominated diphenyl ether and polybrominated and polychlorinated biphenyl levels in human serum from the United States. Environ. Health Perspect. 2004, 112, 654-658.

(13) Hites, R. A. Polybrominated diphenyl ethers in the environment and in people: A meta-analysis of concentrations. Environ. Sci. Technol. 2004, 38, 945-956.

(14) Sjödin, A.; Patterson, D. G. Jr.; Bergman, Å. A review on human exposure to brominated flame retardants (BFRs) - particularly polybrominated diphenyl ethers (PBDEs). Environ. Int. 2003, 29, 829-839.

(15) Johnson-Restrepo, B.; Kannan, K.; Rapaport, D.; Rodan, B. Polybrominated diphenyl ethers and polychlorinated biphenyls in human adipose tissue from New York. Environ. Sci. Technol. 2005, 39, $5177-$ 5182.

(16) Thuresson, K.; Bergman, Å.; Jakobsson, K. Occupational exposure to commercial decabromodiphenyl ether in workers manufacturing or handling flame retarded rubber. Environ. Sci. Technol. 2005, 39, 19801986.

(17) Bergman, Å.; Klasson Wehler, E.; Kuroki, H. Selective retention of hydroxylated PCB metabolites in blood. Environ. Health Perspect. 1994, 102, 464-469.

(18) Letcher, R. J.; Klasson Wehler, E.; Bergman, Å. Methyl sulfone and hydroxylated metabolites of polychlorinated biphenyls. In New Types of Persistent Halogenated Compounds; Paasivirta, J., Ed.; Springer-Verlag: Berlin, 2000; Vol. 3, Chapter 11.

(19) Brouwer, A.; Morse, D. C.; Lans, M. C.; Schuur, A. G.; Murk, A. J.; Klasson Wehler, E.; Bergman, Å.; Visser, T. J. Interactions of persistent environmental organohalogens with the thyroid hormone system: Mechanisms and possible consequences for animal and human health. Toxicol. Ind. Health 1998, 14, 59-84.

(20) Lans, M. C.; Klasson Wehler, E.; Willemsen, M.; Meussen, E.; Safe, S.; Brouwer, A. Structure-dependent, competitive interaction of hydroxy-polychlorobiphenyls, -dibenzo- $p$-dioxins and - dibenzofurans with human transthyretin. Chem. -Biol. Interact. 1993, 88, 7-21.

(21) Malmberg, T., Identification and characterisation of hydroxylated PCB and PBDE metabolites in blood. Congener specific synthesis and analysis, PhD, Department of Environmental Chemistry, Stockholm University, 2004.

(22) Sjödin, A.; Hagmar, L.; Klasson Wehler, E.; Björk, J.; Bergman, Å. Influence of the consumption of fatty Baltic Sea fish on plasma levels of halogenated environmental contaminants in Latvian and Swedish men. Environ. Health Perspect. 2000, 108, 1035-1041.

(23) Hagmar, L.; Rylander, L.; Dyremark, E.; Klasson Wehler, E.; Erfurth, E. M. Plasma concentrations of persistent organochlorines in relation to thyrotropin and thyroid hormone levels in women. Int. Arch. Occup. Environ. Health 2001, 74, 184-188.

(24) Soechitram, S. D.; Athanasiadou, M.; Hovander, L.; Bergman, Å.; Sauer, P. J. J. Fetal exposure to PCBs and their hydroxylated metabolites in a dutch cohort. Environ. Health Perspect. 2004, 112, 1208-1212. 
(25) Fängström, B.; Athanasiadou, M.; Grandjean, P.; Weihe, P.; Bergman, Å. Hydroxylated PCB metabolites and PCBs in serum from pregnant Faroese women. Environ. Health Perspect. 2002, 110, 895-899.

(26) Sandau, C. D.; Ayotte, P.; Dewailly, E.; Duffe, J.; Norstrom, R. J. Analysis of hydroxylated metabolites of PCBs (OH-PCBs) and other chlorinated phenolic compounds in whole blood from Canadian Inuit. Environ. Health Perspect. 2000, 108, 611-616.

(27) Cuadra, S. N., Linderholm, L., Athanasiadou, M., Jensen, S., and Jakobsson, K., Persistent organic pollutants in Nicaraguan women with high consumption of fish from lake Xolotlán, and in children working in a waste sisposal site in Managua, Organohalogen compounds 2003, 64, 83.

(28) Sandanger, T. M.; Dumas, P.; Berger, U.; Burkow, I. C. Analysis of HO-PCBs and PCP in blood plasma from individuals with high PCB exposure living on the Chukotka Peninsula in the Russian Arctic. Journal of Environmental Monitoring 2004, 6, 758-765.

(29) Meironyté Guvenius, D.; Aronsson, A.; Ekman-Ordeberg, G.; Bergman, Å.; Norén, K. Human prenatal and postnatal exposure to polybrominated diphenyl ethers, polychlorinated biphenyls, polychlorobiphenylols and pentachlorophenol. Environ. Health Perspect. 2003, 111, 1235-1241.

(30) Grandjean, P.; Bjerve, K. S.; Weihe, P.; Steuerwald, U. Birthweight in a fishing community: significance of essential fatty acids and marine food contaminants. International Journal of Epidemiology 2001, 30, 12721278.

(31) Steuerwald, U.; Weihe, P.; Jorgensen, P. J.; Bjerve, K.; Brock, J.; Heinzow, B.; Budtz-Jorgensen, E.; Grandjean, P. Maternal seafood diet, methylmercury exposure, and neonatal neurologic function. $J$. Pediatr. 2000, 136, 599-605.

(32) Phillips, D. L.; Pirkle, J. L.; Burse, V. W.; Bernert, J. T. J.; Henderson, L. O.; Needham, L. L. Chlorinated hydrocarbon levels in human serum: effects of fasting and feeding. Arch. Environ. Contam. Toxicol. 1989, 18, 495-500.

(33) Ballschmiter, K.; Mennel, A.; Buyten, J. Long chain alkyl-polysiloxanes as non-polar stationary phases in capillary gas chromatography. Fresenius J. Anal. Chem. 1993, 346, 396-402.

(34) Marsh, G.; Hu, J.; Jakobsson, E.; Rahm, S.; Bergman, Å. Synthesis and characterization of 32 polybrominated diphenyl ethers. Environ. Sci. Technol. 1999, 33, 3033-3037.

(35) Örn, U.; Eriksson, L.; Jakobsson, E.; Bergman, Å. Synthesis and characterization of polybrominated diphenyl ethers - unlabelled and radiolabelled tetra-, penta- and hexa-bromodiphenyl ethers. Acta Chem. Scand. 1996, 50, 802-807.

(36) Bergman, Å.; Nilsson, A.; Riego, J.; Örn, U. Synthesis of ${ }^{14} \mathrm{C}$-labelled and unlabelled coplanar polychlorinated biphenyls (PCBs). Acta Chem. Scand. 1990, 44, 1071-1076.

(37) Sundström, G. Polychlorinated biphenyls II. Synthesis of some tetra- and pentachlorobiphenyls. Acta Chem. Scand. 1973, 27, 600-604.

(38) Bergman, Å.; Klasson Wehler, E.; Kuroki, H.; Nilsson, A. Synthesis and mass spectrometry of some methoxylated PCB. Chemosphere 1995, 30, 1921-1938.

(39) Fieser, L. F.; Fieser, M. Reagents for organic synthesis. John Wiley and Sons: New York, 1967; Chapter 1.

(40) Hovander, L.; Athanasiadou, M.; Asplund, L.; Jensen, S.; Klasson Wehler, E. Extraction and cleanup methods for analysis of phenolic and neutral organohalogens in plasma. J. Anal. Toxicol. 2000, 24, 696703.

(41) Sjödin, A., Occupational and dietary exposure to organohalogen substances, with special emphasis on polybrominated diphenyl ethers, PhD, Department of Environmental Chemistry, Stockholm University, 2000.

(42) Esmen, N.; Hammond, Y. Long-normality of environmental sampling data. J. Agric. Food Chem. 1977, A12, 29-41.

(43) Bignert, A., Biological aspects and statistical methods to improve assessments in environmental monitoring, PhD, Department of zoology, Stockholm University, 2003.

(44) Gilbert, R. O. Statistical methods for environmental pollution monitoring. Van Nostrand Reinhold: New York, 1987.

(45) Helsel, D. R.; Hirsch, R. M. Statistical methods in water resources. Environmental Science 1985, 49.

(46) Fängström, B.; Athanasiadou, M.; Athanassiadis, I.; Bignert, A.; Grandjean, P.; Weihe, P.; Bergman, Å. Polybrominated diphenyl ethers and traditional organochlorine pollutants in fulmars (Fulmarus glacialis) from the Faroe Islands. Chemosphere 2005, 60, 836-843.

(47) Lindström, G.; Wingfors, H.; Dam, M.; van Bavel, B. Identification of 19 polybrominated diphenyl ethers (PBDEs) in long-finned pilot whale (Globicephala melas) from the Atlantic. Arch. Environ. Contam. Toxicol. 1999, 36, 355-363.

(48) Thomsen, C.; Lundanes, E.; Becher, G. Brominated flame retardants in archived serum samples from Norway: a study on temporal trends and the role of age. Environ. Sci. Technol. 2002, 36, 1414-1418. 
(49) Jakobsson, K., Thuresson, K., Sjödin, A., Hagmar, L., and Bergman, Å., A summary of exposures to polybrominated diphenyl ethers (PBDEs) in Swedish workers, and determination of half-lives of PBDEs, Organohalogen Compounds 2003, 61, 17.

(50) Verreault, J.; Gabrielsen, G. W.; Chu, S.; Muir, D. C. G.; Andersen, M.; Hamaed, A.; Letcher, R. J. Flame Retardants and Methoxylated and Hydroxylated Polybrominated Diphenyl Ethers in Two Norwegian Arctic Top Predators: Glaucous Gulls and Polar Bears. Environ. Sci. Technol. 2005, 39, 6021-6028.

(51) Longnecker, M. P.; Wolff, M. S.; Gladen, B. C.; Brook, J. W.; Grandjean, P.; Jacobson, J. L.; Korrick, S. A.; Rogan, W. J.; Weisglas-Kuperus, N.; Hertz-Picciotto, I.; Ayotte, P.; Stewart, P.; Winneke, G.; Charles, J.; Jacobson, S. W.; Dewailly, E.; Boersma, E. R.; Altshul, L. M.; Heinzow, B.; Pagano, J. J.; Jensen, A. A. Comparison of polychlorinated biphenyl levels across studies of human neurodevelopment. Environ. Health Perspect. 2003, 111, 65-70.

(52) Pavuk, M.; Cerhan, J. R.; Lynch, C. F.; Schecter, A.; Petrik, J.; Chovancova, J.; Kocan, A. Environmental exposure to PCBs and cancer incidence in eastern Slovakia. Chemosphere 2004, 54, 1509-1520.

(53) Barr, D. B.; Weihe, P.; Davies, D.; Needham, L.; Grandjean, P. Serum polychlorinated biphenyl and organochlorine insecticide concentration in a Faroese birth cohort. Chemosphere 2005, In press.

(54) Brouwer, A.; Ahlborg, U. G.; van den Berg, M. Functional aspects of developmental toxicity of polyhalogenated aromatic hydrocarbons in experimental animals and human infants. Eur. J. Pharmacol. , Environ. Toxicol. Pharmacol. Sect. 1995, 293, 1-40.

(55) Buitenhuis, C., Cenijn, P. C, Lilienthal, H., Malmberg, T., Bergman, Å., Gutleb, A. C., Legler, J., and Brouwer, A., Effects of prenatal exposure to hydoxylated PCB metabolites and some brominated flame retardants on the development of rats, Organohalogen Compounds 2004, 66, 3586.

(56) Meerts, I. A. T. M.; Hoving, S.; van den Berg, J. H. J.; Weijers, B. M.; Swarts, H. J.; van der Beek, E. M.; Bergman, A.; Koeman, J. H.; Brouwer, A. Effects of in utero exposure to hydroxylated polychlorinated biphenyl on developmental landmarks, steroid hormone levels and female estrous cyclicity in rats. Toxicol. Appl. Pharmacol. 2001.

(57) Meerts, I. A. T. M.; Assink, Y.; Cenijn, P. H.; van den Berg, J. H. J.; Weijers, B. M.; Bergman, Å.; Koeman, J. H.; Brouwer, A. Placental transfer of a hydroxylated polychlorinated biphenyl and effects on fetal and maternal thyroid hormone homeostasis in the rat. Toxicol. Sci. 2002, 68, 361-371.

(58) Ginsberg, G.; Hattis, D.; Sonawane, B. Incorporating pharmacokinetic differences between children and adults in assessing children's risks to environmental toxicants. Toxicol. Appl. Pharmacol. 2004, 198, 164183.

(59) Malmberg, T.; Hoogstraate, J.; Bergman, A.; Wehler, E. K. Pharmacokinetics of two major hydroxylated polychlorinated biphenyl metabolites with specific retention in rat blood. Xenobiotica 2004, 34, 581-589.

(60) Hovander, L., Linderholm, L., Athanasiadou, M., Athanassiadis, I., Trnovec, T., Kocan, A., Petrik, J., and Bergman, A., Analysis of PCB and PCB metabolites in humans from eastern Slovakia, Organohalogen Compounds 2004, 66, 3525.

(61) Sandau, C.; Ayotte, P.; Dewailly, E.; Duffe, J.; Norstrom, R. J. Pentachlorophenol and hydroxylated polychlorinated biphenyl metabolites in umbilical cord plasma of neonates from coastal populations in Quebec. Environ. Health Perspect. 2002, 110, 411-417. 